\title{
Selim İleri'nin “Kapalı İktisat”ını Açmak: Melankoli, Politika ve Mecralar Arasılık
}

\author{
FATIH ALTUĞ
}

\begin{abstract}
ÖZ
Bu makalede, Selim İleri’nin “Kapalı İktisat” öyküsünü çözümleyerek öyküyü biçimsel ve tematik olarak tarihsel bağlamı ve Türk edebiyatı içerisinde konumlandırmak amaçlanmaktadır. Öykü kişisinin öznelliğini anlamaya çalışırken melankoli kavramından yararlanılacak ve bunun öyküdeki kişisel, toplumsal ve metinsel tezahürleri birbirleriyle ilişkileri içerisinde incelenecektir. Metnin kapalı ve muğlak anlatısındaki birçok düğüm noktası, melankoli kavramıyla önemli oranda açıklı̆̆a kavuşmaktadır. Öykünün metinler ve mecralar arası veçhesi ön plana çıkarılacak ve metin dışı kaynakları tespit edilecektir. Öyküde, Ahmet Hamdi Tanpınar'ın “Teslim” öyküsünün, on sekizinci yüzy1l anatomistlerinden Frederik Ruysch'un illüstrasyonlarının, 1977 yılında Milliyet gazetesinde çıkmış bir haberin ve Kadro dergisindeki makalelerin ne şekilde dönüştürülüp temellük edildiği gösterilecektir. "Kapalı İktisat”, tematik ve biçimsel yapısıyla hem İleri edebiyatında bir dönüm noktası oluşturmakta hem de 1980'lerde Türk edebiyatının geçireceği dönüşüme öncülük etmektedir.
\end{abstract}

Anahtar sözcükler: Selim İleri, "Kapalı İktisat”, melankoli, metinler arasilik, mecralar arasilık

Selim İleri'nin ilk olarak Bir Denizin Eteklerinde (1980) kitabında yayımSlanan "Kapalı İktisat" adlı uzun öyküsü, İleri edebiyatında önemli bir dönüşüm anına denk düşmektedir. Bir yandan bireysel, toplumsal, politik ve ekonomik olanın birbiriyle iç içe geçtiği tematik yapısıyla diğer yandan başka yazarların hikâyelerinden gazete haberlerine, ses kayıtlarından anatomi kitaplarına, dergi makalelerinden arabesk şarkılarına uzanan farklı metin ve

\footnotetext{
* Yrd. Doç. Dr., İstanbul Şehir Üniversitesi, Türk Dili ve Edebiyatı Bölümü/İSTANBUL E-posta: fatihaltug@sehir.edu.tr
} 
mecraları hikâyenin yapısına yediren biçimsel yenilikçiliği ile "Kapalı İktisat", İleri'nin önceki öykülerinden ayrılmaktadır.

Eleştirmenler, hem Bir Denizin Eteklerinde'nin hem de özel olarak "Kapalı İktisat" "n Selim İleri öykücülüğünde bir dönüm noktası olduğunu belirtmişlerdir. Feridun Andaç, Bir Denizin Eteklerindénin İleri'nin yazarlık serüveninde "asıl kırılma noktası" olduğunu -"Kapalı İktisat"a özellikle dikkat çekerek- iddia eder: "Romana açılımı, orada yol alışı, öyküdeki renklerini öylesi bir anlatı dokusuna yansıtması gibi görünmüştü ilkten. Ama bu kitabı, İleri’nin öyküde daha da derinleşip yoğunlaştığını gösteriyordu. Anlatıda ustaca bir bakış, kurgulamada benzersiz bir yapı işçiliğini getiriyordu. Özellikle "Kapalı İktisat”..." (2007: 43). Doğan Hızlan da bu öyküyü biçim kadar içerik açısından da "dönüm noktası" addeder. Hızlan'a göre, daha çok bireyselliği ile öne çıkan İleri kişileri, bu öykü ile birlikte toplumsallaşmakta ve politikleşmektedir. İleri "siyasal düzenimizin ve insanımızın alacalı panoraması[n1]" sunmakta, vurguları ve sunuş şekliyle de toplumcu gerçekçi metinlerden çok daha güçlü bir toplumsallık kazanmaktadır. Yozlaşma, sevgisizlik, sahtelik, acımasızlık ve güvensizlik gibi hâller, başka metinlerden alıntılarla tarihsellik de kazandırılarak öyküde tematize edilmektedir (1996: 288). Enis Batur ise İleri "son öyküler toplamıyla yepyeni bir kimlik koyuyor ortaya" iddiasıyla başlar Bir Denizin Eteklerinde değerlendirmesine. Bu yaklaşımda da "Kapalı İktisat" 1 bir ara metin olarak görme eğilimi vardır. Öykü ile roman arasında konumlanmıs ancak bu konumda bir istikrara kavuşamamış bir sınır-metindir "Kapalı İktisat”. Bu durumun zaafları ve erdemlerini Batur şöyle ifade eder:

'Kapalı İktisat'ta da, 'Bir Denizin Eteklerinde'[de] de ayrı ayrı 'roman gereçleri' kullanıyor yazar: (...) Romansal bir yapı, romansal bir perspektif, romansal bir iskelet sanki yorularak 'kısa kesiliyor' her iki öyküde de. 'Kapalı İktisat', her şeye karşın, ustalıkla kurgulandığı, vurucu izleklerle yolunu sürdürdüğü için okuru da kesintisiz kılabiliyor. Kişi olsa olsa yeterince kimi tuzakların arasında oyalanmadığına, bu duyar11 haritayı iyice tarama olanağını bulamadan haritanın elinden çekilip alınmasına hayıflanıyor. Özetle: 'Kapalı İktisat' bir bakıma okurdan esirgenmiş bir anlatı; anlaşılmadık bir cimrilikle kısa kesilmiş bir uzun hava - hele 'Memento Mori'li final. (1993: 278)

Füsun Akatlı için de Bir Denizin Eteklerinde, İleri edebiyatında olumlu anlamda değişimin "ilk tohumları"nın atıldığı metindir. O da Batur gibi, kitaptaki "Kapalı İktisat” ve "Bir Denizin Eteklerinde” öykülerini romanlaşamamış, romanla öykü arasında kalmış metinler olarak kabul eder. Her iki öykünün de "çok verimli uzanımları ve açılımları" vardır. "Kapalı İktisat”, kitabın diğer öykülerindeki "onca yoğun, onca vurucu biçimde yansıyan izleksel bildiriyi dengeleyen ya da dengede tutan durulmuş, din(gin)lendirilmiş bir ara-geçe" (1982: 228). 
Eleştirmenlerin "Kapalı İktisat" 1 ve Bir Denizin Eteklerinde’nin İleri edebiyatında bir dönüm noktası olduğu konusunda hemfikir olduğu görülüyor. Aynı zamanda eleştirmenler, "Kapalı İktisat" numlandırıyorlar. Hem türler arasında hem de kitabın diğer öyküleri arasında bulunan bir eşik. Yoğunluk ve nispeten kapalılık metne atfedilen belli başlı değerler. Bu makalede, Enis Batur'un "duyarlı harita” olarak tanımladığı "Kapalı İktisat” 1 derinlemesine çözümlemek, öykünün haritasında saklı kalmış olan bazı noktaları açığa çıkarmak amaçlanıyor. Öncelikle İleri'nin simgeselleştirdiği ve yoğunlaştırdığı bu kapalı metin, melankoli kavramı aracıllğıyla açılmaya, açımlanmaya çalışılacaktır. İkinci aşamada melankoliyle bağlantısını yitirmeden, metinde bireysel, toplumsal ve politik olanın nasıl iç içe geçtiği gösterilecektir. Her iki aşamada da metnin, olay örgüsünü kurarken başka metinleri ve mecraları anlatısının dokusuna nasıl yedirdiği de özellikle vurgulanacaktır. Bu durumda, makalenin kullanacağı iki temel kavram melankoli ve mecralar arasılık kavramları olacaktır. Melankoli kavramı sonraki bölümde tanımlanacağından bu aşamada Türkçe eleştiri söyleminde pek yaygın kullanımı olmayan "mecralar arasılık" kavramını tanımlamakta fayda olduğu düşünülmektedir. Bir metnin mecralar arası niteliğinden söz edildiğinde o metnin başka metinler kadar başka mecralarla (ortamlarla, medyumlarla) da alıntılamaya, aktarmaya, çevirmeye, dönüştürmeye dayalı bir ilişki içerisinde olduğu ifade edilmektedir. Edebi mecraya, gazete, radyo, televizyon, sinema, resim gibi işitsel ve görsel mecralardan akışın olduğu, bir metnin salt matbu ve edebi olandan ibaret olmadığı bir durum söz konusudur. ${ }^{1}$ Makale boyunca gösterileceği gibi, "Kapalı İktisat” başka metinler kadar başka mecraları bünyesinde dahil eden bir metinselliğe sahiptir. Metnin çözümlenmesi esnasında yapılan araştırmalarda, İleri'nin öyküsünün Tanpınar'ın bir öyküsünü ve o öykünün ses kaydını, Milliyet gazetesinden bir haberi ve 18. yüzyıldan Hollandalı bir anatomistin yaptığ1 illüstrasyonları çeşitli biçimlerde anlatısına dahil ettiği tespit edilmiştir. Bu açıdan makale bu öykünün maddi oluşum sürecine dair de bazı katkılar içermektedir.

\section{Melankolik Öznellik}

“Kapalı İktisat”, üç epigrafla başlıyor. “...sanki bir cehennem trenine binmiştim, bütün ölüm duraklarından geçiyorduk...” (1997: 424) şeklindeki birinci alıntı, öykünün kendi içinden aktarılan bir ifadedir. Diğer epigraflar ise Türk inkılabını Faşist İtalya, Nazi Almanyası ve Sovyet Rusya ile karşılaştıran ve Kadro dergisinden alınmış metinlerdir. Daha başlangıçta metnin öz-

1 Mecralar arasılık kavramının edebiyat araştırmalarında ne şekilde kullanılabileceğine dair kapsamlı bir çözümleme için bkz. Rajewsky 2005. 
göndergesel yanı ve politik göndermeleri öne çıkmaktadır. Metnin olay örgüsü ise Sadrazam Koca Hasan Paşa'nın torunu olan ve siyasal bilgiler okumasına rağmen siyasetten uzak ve keyfine düşkün bir yaşamı seçmiş olan anlatıcının, benliğinin parçalandığ 1 ve bu nedenle başına gelenleri bir bütünlük içerisinde toparlayamadığı bir anla başlar. Her şeyin kararında yaşandığ 1 ve yerli yerinde olduğu bir hayatı tecrübe etmekte olan anlatıcı, "[ü]st üste gelen, [kendisini] yıkan, sarsıp aklı[n] yitirme[sine] yol açan birtakım (...) [o]laylar, yaşantılar, duygulanımlar, bölük pörçük, içyüzüne varılamamış izlenimler” (1997: 425) sonrasında artık bambaşka bir hakikatin eşiğine gelmiştir. Ancak yaklaşmakta olduğunu hissettiği bu hakikat, durulukla değil "içinden çıkılamayacak kerte karmaşık[likla]" (1997: 425) nitelenir. İşte böyle bir eşikte konumlanmış olan anlatıcı, önüne bakamadığı, umutla geleceğe yönelemediği bu anında geçmişe dönüp, maruz kaldığ 1 "şey"i anlamlandırmaya çalışır. Mevcut anın, geçmişte yaşadıkları tarafindan derinlemesine belirlendiğini düşünen anlatıcı, hâlinin şeceresini oluşturmaya ve çözümlemeye yönelir:

[B]irtakım olaylar, yaşantılar, duygulanımlar ve bölük pörçük izlenimler arasında sıkı bir örgü olduğunu; bu örgünün bütün bir geleceğe -suda genişleyen, sonra ansızın kaybolan halkalar gibi- etkidiğini ya da etkiyebileceğini ne zaman düşünmeye başladığımı anımsamıyorum. Bir başlangıç bulmalıyım oysa; bulamazsam, neden-sonuç ilişkisini asla çözümleyemeyeceğim. (1997: 425)

Anlatıcı, bu hâle gelişini anlamaya, neden-sonuç ilişkilerine dayalı bir olay örgüsü oluşturarak kendi bütünlüğünü yeniden kurmaya çalışmaktadır ancak ortaya bir örgü ya da şecere değil de bir ağ çıkmaktadır. Olayların başlangıç anına dair üç varsayıma sahiptir ve bu varsayımların birbiriyle bağıntılarını açıklıkla kuramamaktadır. "Kapalı İktisat", büyük oranda anlatıcının inşa etmeye çalıştığı geçmişinin hikâyesidir. Başlangıç varsayımları ve olaylara dair müphemiyetler, -bazı yerlerde bulanıklaşsa da çoğu zaman sadık kalınan- bir kronolojik düzenlemeyle metnin olay örgüsüne / olaylar ağına yedirilir. Anlatıcı, dünyaya dair iki kavrayışın ortasında kalakalmıştır: Maruz kaldığı deneyimlerin sonucunda "hayatımızın dondurulduğunu, tek bir zaman diliminde hep aynı şeyleri yaşamaya başladığımızı hissed[erken]” (425), aynı zamanda sığındığı deniz kıyısında gördüğü en ufak hareketin bile yepyeni başlangıçları tetiklediğine inanmaktadır. Sürekli tekrar eden aynılık ile bambaşka imkânlara gebe küçük bir fark arasındaki gerilim metnin tamamını etkileyecektir.

Artık eski benliği gövdesini terk etmiş olan anlatıcı, bu sürece dair üç başlangıç varsayımını üç karşılaşma ile tanımlar. Bay Cek Cansın aracılığıyla toplumsalla karş1laşma, Melankolinin Anatomisi vesilesiyle evrenselle ve Nedret sayesinde aşkla karşılaşma. Bu üç ihtimal metnin üç bölümünü oluşturacaktır. Diğer iki olayın da bağlı olduğu ve kronolojik olarak diğerlerini önceleyen Nedret'le karşılaşma ilk bölümün odak noktasıdır. "Karasevda" başlıklı bu bölümde anla- 
tıcının eski benliği ve Nedret dolayımıyla başlayan yeni süreç verilir. Anlatıcı, dünya nimetlerine ve hazlarına düşkün birisidir ancak her nimet ve hazzı ölçüyle tatmaktadır. Özellikle cinsel hazzı gelip geçiciliği içerisinde yaşaması ve birlikte olduğu kadınları unutmasıyla bilinen anlatıcı, yeni hâliyle bu döneme baktığında, hafızasının bastırılmış anları açı̆̆a çıkar. Bu anlardan en önemlisi, eski nişanlısı Sema ile ilgili hatırasıdır. Geçmişini kurarken Sema'nın hamile kalması ve sonrasında yalnız başına onu kürtaj olmaya gönderişi bir vicdan sızısı olarak açığa çıkar. Bu anı / görüntü, metnin sonlarına doğru başka anlara ve görüntülere de sızacaktır.

Sema’yı kolaylıkla unutabildiği o döneme geri döndüğümüzde, anlatıcının hayatının çığırından çıkmasına yol açacak o an'a, Yeni Komedi Tiyatrosu'nun fuayesinde Zafer ve Nedret'le karşılaşmasına tanık oluruz. Tiyatroda yeni bir yorumla Hamlet sergilenmektedir ve Ofelya ile Laertes arasındaki diyalog ensest bir aşkı ima edecek şekilde yeniden biçimlendirilmiştir. Üstelik Ofelya'yı oynayan anlatıcının metresidir. Zafer ve Nedret'le karşlaşma bu norm dışı yorumdan hemen sonra gerçekleşmiştir. Bu karşılaşmada anlatıcının geçmişinden gelen bir gizi öğrenir ve geleceğini etkilemeye başlayacak olay örgüsünün ilk ilmeklerinden birini tanırız. Taşralı köklerden gelen ve sınıf atlayan Zafer, anlatıcının yıllardır görmediği çocukluk arkadaşıdır ve ilkokul yıllarında birbirlerinin "cinsel organlarına bakacak kadar içlidışlı" (429) olmuşlardır. Bu saklı geçmiş, sonrasında da anlatıcının zihnini meşgul edecektir. Ancak asıl karşılaşma, Zafer'in eşi Nedret'le olandır. Anlatıcı, ailesi eski sınıfsal konumunu ve itibarını kaybetmiş olan Nedret'e âşık olacak, bu aşkla birlikte bir politikleşme süreci yaşayacak ancak Zafer'den hamile olan Nedret'in doğum sırasında ölümüyle -başka nedenleri de olan- bir yıkıma uğrayacaktır.

Yukarıda ana hatlarıyla gösterilmeye çalışılan, anlatıcının öznelliğini anlamak için melankoli kavramını devreye sokmanın önemli ve işlevsel olduğu düşünülmektedir. Anlatıcının deneyiminde kuvvetli bir kayıp duygusu söz konusudur. Temelde, yasak bir aşkla bağlanılan Nedret'in kaybı vardır. Biraz daha derinlerde ise Sema'nın ve özellikle de doğmamış çocuğunun kaybı kendini sezdirir. Öykü ilerledikçe bu kayıpların şiddeti daha da belirginleşecektir. Ancak anlatıcının bu kayıplar karşısında yaşadığı hâl yastan çok melankoliyi doğurmuştur. Freud, melankolinin belli başlı özelliklerinden "derin acılı bir yeis hali, dış dünyaya ilginin kesilmesi, sevme kapasitesinin kaybı, aktivitelerin inhibisyonu [ketlenmesi] ve (...) kendine saygida azalma hali” (1993: 98) şeklinde söz eder. Yas sürecinde sevilenin kaybı, sevilenden bir türlü kopamama, onun yokluğunu kabullenmeme şeklinde gerçekleşir, ancak bir süre sonra yaşamın gerçekliği ağır basar ve kişi, kayıpla daha gerçekçi bir ilişki kurmaya başlar. Ancak melankolide bu noktaya gelinmez: Melankolik, kaybettiği arzu nesnesini kendi öznelliğine dâhil eder, gerçeklikle uzlaşmaz. Gerçek ya da 
hayali kaybını içselleştirir. Sevilenin kaybından sonra "libido başka bir [arzu] nesne[sin] yatırılmayıp ego'nun içine geri çekilmiştir. Libido burada, terkedilmiş nesne ile özdeşim amacına yönelik olarak kullanılmıştır. Nesnenin gölgesi ego'nun üzerine düşmüş ve ego terkedilmiş bir nesneymiş gibi davranılmaya başlanmıştır. Bu yolla, nesne yitimi ego yitimine dönüşmüş, ego ile sevilen kişi arasındaki çatı̧̧ma ise özdeşim nedeniyle değişmiş ego ile, egonun gerçek etkinlikleri[nin] birbirinden ayrilm[asına]" neden olmuştur (1993: 100).

Nedret'in kaybının anlatıcı üzerindeki işleyişi de benzer şekildedir. Bu kayıptan sonra anlatıcı içe kapanmaya, toplumsal etkinlikler alanından uzaklaşmaya başlamıştır. Öykünün başında ve şimdiki zamanında, şehirden uzakta bir tabiat parçasında, parçalanmış benliğini toparlamaya çalışan anlatıcı kendi içinin sınırlarını bilemez haldeyken başta Nedret olmak üzere kendi içiyle dış dünyanın öğeleri arasındaki sınırı da çizemez haldedir. Gündelik hayatını idame ettiremeyecek kadar parçalanmış olan bu öznenin yaşadığ1 temel duygu müphemiyettir, çift-değerliliktir; Freud'da melankolik durumun temel göstergelerinden biri olarak geçen "ambivalens"tir (1993: 100).

Dünyadaki her değişikliğin yeni bir başlangıç varsayımı doğurabildiği derecede müphemiyetin içerisinde olan anlatıcıyı Nedret'in nasıl bu şekilde etkilemiş olduğuna biraz daha yakından bakalım: Nedret'e duyduğu arzu ilk planda aşk değil, yalnızca bedensel hatta fetişist bir arzudur. Anlatıcı daha önce hiç yaşamadığı bir tecrübeyi yaşamaktadır: Daha önce sevdiği kadınları bedensel bütünlükleri içerisinde arzulayan anlatıcı, Nedret'in koluna arzu duymaktadır (1997: 430). Sürekli "Nedret'in kendi bedeninden ayrı bir varlık gibi yaşayan unutulmaz ellerini” (1997: 432) düşünmektedir. Giorgio Agamben, fetişizm ve melankolinin ortak köklerinden söz eder (Mills 2008: 49-50). Her iki durumda da arzulanan nesne, fiziksel bütünlüğünden koparılarak bir parçaya, bir temsile dönüştürülerek içselleştirilmeye, temellük edilmeye çalış1lmaktadır. İmkânsız arzu nesneleri fetişist ya da melankolik müdahaleyle bir şekilde ikame edilmektedir. ${ }^{2}$ Bu açıdan anlatıcının Nedret'le ilk karşılaşmasında yaşadığ 1 fetişist arzu sonraki melankolik bağın habercisi olarak görülebilir.

Süreç ilerledikçe Nedret imgesine, fiziksel güzelliğin yanı sıra politik tavır da eklenecektir. Anlatıc1, Nedret'in hümanist sosyalist olarak tanımlanabilecek tavrının yavaş yavaş etkisi altına girecek; Nedret politik bir "femme fatale"e (İleri 1997: 439) dönüşecektir. Nedret, anlatıcı için canlandırıcıdır. Hayatının örtülü yanları, Nedret'le birlikte açığa çıkmaktadır. Bu anlamda, Nedret, anlatıcının aslında oldukça politik olan öznellik zeminini görünür kılar ve başka

\footnotetext{
"[M] elankolide nesne ne mal edilebilir ne de kaybedilir, aksine aynı anda hem sahip olunur hem de kaybedilir. Ve fetiş aynı anda bir şeyin ve o şeyin yokluğunun işareti olduğu ve bu tezadı kendi hayaletvari konumuna borçlu olduğu için, melankoli projesinin nesnesi de aynı anda hem gerçek hem de gerçek olmayan; bedene dahil edilmiş ve kayıp, onaylanmış ve reddedilmiştir” (Agamben 2007: 260).
} 
politik ideallere yönlendirir. Anlatıcının da dahil olduğu Sadrazam Koca Halil Paşa'nın ailesi, Osmanlı'dan Cumhuriyet'e geçişin getirdiği prestij kaybını apolitikleşmeyle telafi etmeye çalışmış, mülkünü korumak adına siyasal alandan çekilmiştir. Ancak anlatıcının siyasal bilgiler okumasına rağmen siyasete bulaşmayan kayıtsız tavrı Nedret'le birlikte zayıflamaktadır. Nedret, tam anlamıla bir anti-faşisttir; ona göre faşizm, öncelikle ruhsal düzlemde işleyen bir ideolojidir. Faşizmin; iktisadi, toplumsal boyutları kadar insan ruhunu da egemenliğine alan yanını dikkate almak gerekir. Ingeborg Bachmann'ın 1973'te yaptığı bir söyleşide ifade ettiği faşizmin ilk bomba atıldığında değil kadın ve erkek arasındaki ilişkide başladığına dair konumuna (Hills 2008) yakın bir konumdur Nedret'inki. Faşizmin arzuyla özellikle de cinsel arzuyla ilgili boyutunu önemser. Cinsel doyuma, ancak aşağıladıkları milletlerden, dinlerden, ırklardan insanlarla yatarak ulaşan insanları anlatır (İleri 1997: 437). Faşizmin İtalyan annelerinin gönlünü nasıl çaldığını dile getirir (1997: 440). Hayatı tam anlamıyla anlamak için bireysel boyuta, faşizmin arzu boyutuna bakmak gerekir. Nedret' in ideolojisinde bireysel olanla politik olanın, fikirlerin akışıyla arzunun akışının iç içe geçmesi ve aynı önemde ele alınması, anlatıcıyı Nedret'e daha da çok celp eder. ${ }^{3}$

Nedret'e göre Türkiye'deki toplumsal yaşam insanı sıradanlaştırmakta, adamsendeciliği teşvik etmekte, sınıf atlama uğruna bencilleşmeye yol açmaktadır. Hatta bencillik o raddeye gelmiştir ki insanlar cinayetlere bile göz yumar hale gelmiştir. Bunların da ardında temel bir neden olarak kamuoyu yokluğunu görür (1997: 438). Bu fikirler eşliğinde Nedret ve anlatıcı şehri dolaşmaya başlar. Bu kısımlarında öykü, politik bağlamı daha belirgin bir Mümtaz ve Nuran hikâyesi anlatmaktadır. Çiftin aşkı tecrübe edişiyle şehri keşfedişleri eşzaman11 gelişmektedir. Nedret'in öncülüğünde anlatıcı, bir başka şehirle ve halkla tanışmaktadır. Kendi içine kapalı hayatı, dışarıya, ötekine doğru açılmaktadır. Şehrin mutena mekânlarından “çöküntünün denizi”ne, şehrin yoksul mahallelerine doğru sürüklenmektedirler (1997: 444). Şehrin, farklı öğeleri ve katmanları yan yana barındıran heterojen niteliği, dolaştıkça açı̆̆a çıkmaktadır.

Nedret, anlatıcının politik konumunu etkilemiş, şehirdeki güzergâhlarını çeşitlendirmiş ve en temelde hayatın heterojen karmaşasının farkına varmasını sağlamıştır. İlk başta fetişist bir karakterde ve yalıtılmış olarak başlayan aşk, mahlût bir tecrübeye dönüşmüştür. Nedret'in kıymeti, duyulan aşkın saflığında değil, bu aşkın sürekli başka şeylerle de bağ kurmasını sağlamasındadır.

Nedret'in fikirlerinin oluşumunda ABD'deki yüksek lisans hocası Cek Cansın'ın etkisi sonradan dile getirilse de 1970'lerin Türkiye'sindeki pek yaygın olmayan bu türden bir faşizm analizinin metin dı̧̧ı kaynakları olarak Wilhelm Reich'ın Türkçeye ilk defa 1975 'te çevrilen ve cinsel doyumla faşizm arasındaki ilişkiyi ayrıntılı analiz eden Faşizmin Kitle Rubu Anlayışsı kitabı ve faşizm ve kadınlar arasındaki ilişki bakımından da Cemal Süreya’nın 1977 yılında çevirdiği Maria A. Macciocchi’nin Faşizmin Analizi kitab1 sayılabilir. 
Nedret'le ilgili zihinsel imgeler bile sürekli başka kişilerle ilgili imgeleri çă̆ırmaktadır. Nedret'in hamile olduğunu öğrenmesi, hemen eski nişanlısı Sema ve onun kürtajıyla ilgili saklanmış anıyı harekete geçirmiştir (1997: 436). Zafer ve Nedret'in evliliğine dair tefekküre de Zafer'le yaşadıkları “çocukluk günleri[n]in karmaşık anısı” (1997: 434) eşlik etmiştir. İlkokulda birbirlerine cinsel organlarını göstermelerini Nedret'e anlattığında Nedret'in tepkisi anlamlıdır: Garip olan, herkesin başına gelebilecek böyle bir tecrübeyi yaşamak değil, herkes bu anı unuturken anlatıcının unutamamasıdır (1997: 442). Hemen ardından anlatıcı "bu anıyı silip atmanın imkânsızlığını" düşünür.

Aslında Nedret, anlatıcıda yalnızca kendisiyle, politikayla, halkla yeni bir ilişki imkânını değil, artık geri dönülmesi imkânsız, gerçekleştirilmemiş potansiyellerin anısını da canlandırmaktadır. İlk gruptakiler anlatıcının öznelliğini ferahlatan ve açan etkilere sahipken ikinci gruptakiler anlatıcının kendi üzerine dönüşünü, kapanışını teşvik eder, vicdanını harekete geçirir. Sema ve potansiyel bebeklerinin kürtajı konusundaki kayıtsızlığı sürekli vicdanını meşgul etmeye başlar, Zafer'le gerçekleşen ama devam ettirilmeyen ilişki anı ise eşcinsel arzuyu ima etmektedir. ${ }^{4} \mathrm{Bu}$ anlamda Nedret imgesi, birçok başka imgenin bağıntılı olduğu bir işleve sahiptir: "İmgeler, kopuk kopuk, birbirlerini tamamlayarak, tamamlamak da ne, birbirinden bağımsız diziler, bütünlükler oluşturarak uçuşup geçti” (1997: 436). (Bu alıntıda, imgelerin heterojen terkipler oluşturduğuna dikkat edilmeli.) Dolayısıyla Nedret'in doğum esnasındaki ölümü, yalnızca sevilen bir kadının kaybını değil, gerçekleşmiş ya da gerçekleşememiş tüm bu imkânların kaybını da içerdiğinden anlatıcının melankolik deneyimi daha parçalayıcı bir hâle bürünmüştür. Anlatıcının hâli tam anlamıyla aşk melankolisi ile örtüşmektedir: "Bir adım daha atıp işi söze, sözcüklerin açıldığ 1 anlama dökünce, asıl zedelenenin imgelem olduğu anlaş1ır. Aşk melankolisiyle acı çekenin, düşlemlerinde yitirdiği ya da asla ulaşamadığı âşı̆̆ıyla yaşadığı mutlu anlardan karabasanlara uzanan bir imge cümbüşünde, gerçekle olan bağını koparmış olduğu cümlelerine yansır" (Göle 2007: 165). $\mathrm{Bu}$ ifadeler, anlatıcının melankolik öznelliğinin kurduğu bir metin olarak "Kapalı İktisat" 1 da nitelemektedir.

Kayıpları birleştiren ve melankoliyi tetikleyen bir figür olarak Nedret'in, aynı zamanda melankolinin bir niteliği olduğunu söylediğimiz müphemiyetle bağlantılı örneklerde de merkezde olduğunu görürüz. Anlatıcı, Nedret'in yasını tutarken, “[n]e kaygılar bitiyordu, ne de yıkılmışlı̆̆ın görüntüleri” (1977: 460) şeklinde düşündüğü bir anda Zafer’in kapısını çaldığını görür, Zafer kapıda

\footnotetext{
4 Judith Butler'ın "Melankoli ve Toplumsal Cinsiyet - Reddedilmiş Özdeşleşme” makalesi (2007), heteroseksüelliğin eril ve dişil konumları tesis ederken diğer cinsel bağlllıkların imkânını önlediğini, eşcinselliğin peşinen reddedilmesine ve "yaşanamaz tutku, kederlenilemez kayıp" (278) olarak yaşanmasına yol açı̆ğını vurgular. Anlatıının, Zafer'le ilgili anıları bu türden bir cinsiyet melankolisine de işaret eder.
} 
Sema ile birliktedir. Eflatun bir güneş ışı̆̆ının Zafer-Sema çiftini silmesinden hemen sonra Nedret'in fotoğraflarına baktığında ise Nedret'in yerine Sema’nın geçtiğini görür. Anlatıcının kayıp imkânlarıyla bağlantılı bu üç figür iç içe geçmiş, aralarındaki sınırlar bulanmıştır. Bu halüsinatif anda, örtük

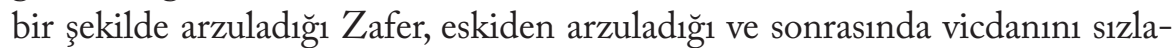
$\tan$ Sema ile eşleşmekte, hemen ardından da kayıp arzu nesnesi Nedret'ten Sema'ya dönüşmektedir. Bu durumda Nedret'in kaybı yalnızca onun kaybı değil, bu karmaşık arzu ilişkilerinin şirazesinin çıkması, gerçeklik zeminini yitirmesi anlamina da gelir.

Ancak Nedret'in kaybı yalnızca bireysel, cinsel ve romantik alanda kayıplarla bağlantılı değildir. Nedret'le eşzamanlı olarak politik bir imkân da kaybolur ve bu kayıp da anlatıcının melankolisinde kuvvetli bir paya sahiptir. Freud da yas ve melankolideki kaybın bir kişi kadar, vatan ya da ideal kaybı da olabileceğini söyler (1993: 98). Anlatıcı, Nedret aracılığıyla politikleşmiş ama kısa sürede ülkede yaşanan gelişmeler sonucunda idealini ve toplum tahayyülünü de kaybetmiştir.

\section{Kökler ve Politika}

Her ne kadar anlatıcı, Nedret aracılığıyla politikleşse de Nedret'i de politikleştiren figür olan Cek Cansın'ın Türkiye'ye gelmesi ile öykünün politik vurgusu şiddetlenir. Öykünün başlığından epigraflarına kadar ima edilen politik-iktisadi ton, bu ziyaretle birlikte merkezileşir. Hatırlanacağı üzere, anlatıcının kendisinin bu hâle gelmesine neden olarak gördüğü başlangıç varsayımlarından biri de Cek Cansın’ın bu ziyaretidir. "Bay Cek Cansın” başlı̆̆ını taşıyan ikinci bölümle birlikte öykünün metinler ve mecralar arası niteliği de yoğunlaşır. Cansın, Türkiye toplumu üzerine analizlerini, yeni yeni ilgilenilmeye başlanan ancak yalnızca "aşk ve İstanbul'un romancısı" (1997: 451) sanılan bir yazarın öyküsü aracıllğ̆ıyla ifade eder. Cansın'ın ima ettiği yazar Ahmet Hamdi Tanp1nar, öykü ise "Teslim”dir. Cansın "Teslim” in önemli bulduğu noktalarını okur ve yorumlar, anlatıcı bu seansı teybe kaydeder. Geçmişi yeniden inşa ederken bu teyp kayıtlarını dinleyerek okura aktarır. Böylelikle Tanpınar'ın öyküsü iki kere dolayımlanarak okura ulaşır. Önce Cansın, öyküden belli kısımları seçer, sonrasında da bu seçim ses kaydı aracılığıyla öykünün şimdiki zamanına ulaşıp metne bu sefer yazıyla kaydedilir. Cansın'a göre Türkiye'nin kaderi çoktan çizilmiştir. Kültürel seferberliği gerçekleştiremeyen, kitle kültürüne yenik düşen, cehaleti aşamayan bir Türkiye, kendi iradesini de eline alamamıştır. Ancak Tanpınar'ın öyküsü aracıllğ̆ıla bu analizini çok daha derinleştirme firsatı bulur. Emin Bey'in halkın değerlerine teslim oluşunun anlatıldığı "Teslim” öyküsünde, Türkiye halkının köklü işleyişine dair tespitler de söz konusudur. Emin Bey, politikanın büyük merkezlerde belirlenen bir fikir davası olmadığını tam 
da yerelde -toprak ve pazarla bağlantılı bir şekilde- asıl politikanın açığa çıktığını düşünmektedir. Politikayı belirleyen şey, kişilerin ifade ettiği sözler değil, kamusal alanda takındıkları beden dili, icra ettikleri jestler, bir sözü söylerken sakladıkları ya da bir şeyi saklarken söyledikleridir:

'Daha ilk günlerde bu insanların kendisinden kendisine benzeyenlerden çok başka türlü bir yaradılışta olduğunu, kafalarında bir yığın gizli ve şaşmaz hesap bulunduğunu hissetmişti. Sırasında ağır ağır, kelimeleri tarta tarta konuşurlar...' (Bay Cek Cansın'ın nefes alışı.) ‘... sırasında bir hiçin etrafinda saatlerce süren bir gevezelikte kendilerini gizlemeyi bilirlerdi.' (Nedret, "Sen de çay ister misin?" diye sormuş. Herhalde hayır anlamına başımı sallamışım: Sesli bir yanıt yok.) 'Birbirlerinin kudretlerini tek bir bakışta ölçüyorlar, lâhzada açmazlar kuruyorlar, dostça gülüyorlar, hemen ilk firsatta iki tarafın da bozacağ i ittifaklar aktediyorlard.' (Ben öksürmüşüm.) 'Dışardan şöyle bir kulak kabartınca acemi bir hasır örgüsüne benzeyen, onun gibi birbiri üstünden atlayan, birbirini saran, yarı lâtife, bir yığın mizaç tiryakiliği dolu ve bu yüzden son derece zararsız görünen bu konuşmalarda her şey mühimdi.'Bakın, bundan sonrasında değerli yazarınız birkaç jestle hangi dünyagörüşünün yaygınlık kazanacağını betimliyor: 'En küçük çehre değişikliğinin' (Bay Cek Cansın çayından içmiş.) '... bir el işaretinin, şöyle bir yan bakışın, eldeki tespihin birdenbire toplanıp cebe konmasının, uzat şu tabakayı yeğen kabilinden mânâsız bir cümlenin altında çok mühim kararlar, muazzam ve belki yıkıcı sırlar vardı.' (1997: 449)

Alıntılanan bu ifade, "Kapalı İktisat" 1 temasına, politik konumuna ve biçimine dair önemli içerimleri kendisinde toplamaktadır. Anlatının söylemi de heterojendir burada: Şimdiki zamandan teyp aracillğıyla aktarılan bir metnin okunması ve bu esnadaki bağlam, yani metin, mecra ve özneler arası ilişkiler, noktalama işaretleri aracılığıyla da gösterilen bir özenle yan yana getirilmektedir. "Teslim"den yapılan alıntı kadar bu alıntıyı kuşatan bağlam da aktarılmakta, "Teslim" salt bir tematik araca indirgenmemektedir. Bununla birlikte Cek Cansın için burada ifade edilen "halk bilgisi", Tanpınar gibi iyi bir edebiyatç1nın sezdiği ama karar vericilerin dikkate almadığı bir bilgidir. Halk, "Teslim" öyküsünde, kolaylıkla bilinebilir, incelenebilir, ele geçirilebilir şeffaf bir varlık olarak sunmaz kendini. Açıklıkla muğlaklık arasında gidip gelen kendisine özgü bir dinamiğe ve statiğe sahiptir. "Bu şifreleri çözemezs[e]niz, iyi maskelenmiş kuvvetler gibi yaşayan (...) bu insanların dünyasında her şeyi kaçırmış olurdunuz. Fakat çözdüğünüz zaman da fazla bir şey öğrenmiş olmazdınız. Çünkü bu kaynayışın altındaki büyük cihaz, onu sevk ve idare eden ihtiraslar, davalar sizin yabancısı olduğunuz şeylerdi” (1997: 450). “Teslim” in anlatıcısına göre "cihaz", "hayat makinesi" gibi işleyen halk, bilgi nesnesi olmaya direnen iç ve derin bir işleyişe sahipti. Hayatın her anının bir programa göre yaşandığı ve doğumdan ölüme her eylemin politikasının belirlenmiş olduğu bir durumdur söz konusu olan. Cek Cansın için, Tanpınar'ın karakteri Emin Bey'in tecrübe 
ettiği bu "halk bilgisi", ülkede bireyselliğin ve kamuoyunun oluşamamasının asli kaynaklarını göstermektedir. Bu şekilde yaşanan bir hayat, bir yandan dayanışmayı mümkün kılarken diğer yandan da farklılaşmayı engellemektedir. Topluluk dayanışmasının bireysel farklılaşmaya izin vermediği, sözel iletişimin, açık eylemlerin hayatı anlamada yeterli olamadığı bu düzen, Cansın’a göre faşizan eğilimleri desteklemektedir. "Teslim”in Emin Bey’i bütünlükle fark arasındaki bu gerilimi köklülük kavramıyla açıklamaktadır:

'Emin Bey şehrin bu gizli hayatını gördükçe bazı ideologların sık sık kullandıkları k ö k1 ü kelimesinin mânasını anlar gibi oluyordu. Güneş altında görünen yaprak ve dallardan, gövdelerden ayrı, toprağın karanlığında, kendilerine ait çok başka, çok derin ve kesif, mahşerimsi mücadeleler ve hamlelerle dolu bir hayatları vard. Orada birbirlerine kenetleniyorlar, birbirlerini sıkıştırıyorlar, birbirlerinin yaşama imkânlarını azaltıp çoğaltıyorlardı.' (1997: 450)

Metinde özellikle "kök1 ü" şeklinde yazılarak vurgulanan ifadeyi kullanan ideologlardan en önemlileri, Tanpınar'ın aşina olduğunu, Yahya Kemal'in etkilendiği bilinen Fransız sağının etkili entelektüellerinden Maurice Barrès ve Charles Maurras'tır. Her iki düşünür için de köklülük kavramı, politikayı belirleyecek ideal durum olarak memlekete, halka ve toprağa, yani köklere yakın olmak, yersiz yurtsuz, köksüz olmamak şeklinde addedilmektedir (Davies 2002: 86). Ancak bu düşünürlerden farklı olarak Emin Bey'in kök kavrayışı çift değerlidir: Aynı anda hem kenetler hem de sıkıştırır, biz'in yoğunluğunu artırırken ben'in farklılığına izin vermez. Yine de öykünün sonunda Tanpınar'ın karakteri Emin Bey, bu köklere teslim olur. Ancak bu teslimiyet Tanpınar'da sıkça gördüğümüz geleneğin estetik kökleriyle ilişki kurmaktan farklı bir durumdur. Bu köklerin ele alınışına, olumlanıp olumlanmadığına dair öyküde bir müphemiyet vardır. İleri'nin karakteri Cek Cansın, Emin Bey'in teslim oluşundan bağımsız olarak Emin Bey'in tespitlerini mevcut Türkiye toplumunun gerçekçi bir betimlemesi addeder. Bu metinler arası ilişki aracilı̆̆ıla İleri’nin karakteri, Tanpınar'ın karakterinin faşizm vurgusunu daha da şiddetlendirir. ${ }^{5}$ Cek Cansın dolayımıyla Tanpınar'ın öyküsüyle karşılaşması anlatıcının toplum tahayyülünü derinden etkiler. Nedret dolayımıyla yeni bir toplumsallık fikrine ulaşan, başka türlü bir yaşama şeklini umut eden anlatıcı, Cek Cansın'ın yorumları sonrasında ülkenin kaderinin çoktan çizildiği, her şey için çok geç kalındığı fikrine meyletmeye başlar. Tanpınar'ın öyküsünde Emin Bey'in betimlediği koşullar bireyselliği ve kamuoyunu oluşturacak şekilde dönüştürüle-

\footnotetext{
Aslında “Teslim” öyküsü, Tanpınar'ın siyasal, sosyal ve iktisadi görüşlerini ve bu görüşlerin edebîleşmiş formlarını düşünmek için önemli imkânlar sunar. Hilmi Yavuz ile Selahattin Hilav arasında 1973 yıllnnda gerçekleşen Tanpınar'ın solla ilişkisine dair tartışmaya bu öykünün girmemiş olması önemli eksiktir. Halbuki Tanpınar düşüncesinin Barrès ve Maurras'la bağlantısı(zlığı) bu tartışmanın gündemine girebilmiştir. Tartı̧̧ma için bkz. Hilav 2008a, 2008b; Yavuz 2008.
} 
mediği için toplumun köklü nitelikleri ile dışarıdan çizilen planlar bir araya gelecek ve hayat artık yaşanamaz olacaktır. Bu noktada art arda gelen birbiriyle bağlantılı iki haber, anlatıcının bu fikirlerini şiddetlendirir. Sağcılar bir solcu genci öldürmüş, hemen ardından da psikiyatri okuyan bir gencin de aralarında bulunduğu bir grup solcu, iki sağcı iş̧̧iyi işkenceyle öldürmüştür. Anlatıcı için bu iki olay, başka türlü bir toplumsal imkânın kaybının tescillenişi, faşizmin işleyişinin bir göstergesidir. Ancak nasıl ki Nedret için faşizm iki insan arasındaki ilişkide başlıyorsa burada da iki karşıt ideolojiyi de ele geçirmiş olan çok daha asli bir mesele olarak öne çıkar faşizm. Anlatıcının politik ideal kaybının anlatıldığı bu kısımlarda metinler arasılık yine devreye girer. Metinde haber formatına uygun olarak ve ayrıntılı bir şekilde verilen "Solcu Genci Sağcıların Öldürdüğü Açıklandı” haberinin kaynağını araştırırken, kurmaca haberin, 22 Şubat 1977 tarihinde Milliyet gazetesinde yayımlanan Namık Koçak'ın "Cenazeden Sonra Bir Kişi Öldürüldü” başlıklı haberinin yeniden yazımı olduğu tespit edildi. Metnine Tanpınar'ın öyküsünden bazı parçaları aynen dâhil eden İleri, aynı zamanda bir gazete haberine de formatını değiştirmeden ama içeriğini dönüştürerek gönderme yapar. Olayın failleri ve işbirlikçileri olan Ümit Deniz Kulluk, Raci Özbek, Fikret Öğültürk, Abdullah Azizoğlu, hayatlarıyla ilgili verilen ayrıntılara sadık kalınarak sırasıyla Mehmet Ali Özer, Ramiz Kesepli, Turhan Oğuzalp ve Bekir Yılmaz isimlerini alarak kurmaca habere dâhil edilmiştir. Gerçek hayatta yakalandıkları evin bulunduğu Fatih'teki Namık Kemal Caddesi ise Silistre Caddesi olarak değiştirilmiştir. Yalnızca birkaç örneği verilen bu yeniden yazım aracıllı̆̆ıla İleri, metnin 1980'deki okurlarının hafizasında canlı olması muhtemel olaylara göndermede bulunmuş, metnin politik vurgusunu şiddetlendirmiştir. Bu vurgunun sağ-sol kutuplaşmasının çok daha ötesinde, her iki kesimin de girebildiği bir faşizm hâline yapıldığ1 tekrar hatırlatılmalıdır. Tanpınar'ın öyküsü aracilığıyla "Kapalı İktisat"ın faşizm analizi "köklü"lük kazanırken, hemen ardından gelen gazete haberiyle de güncellik sağlanmıştır.

Bu bölümde anlatılan politik düzlem dikkate alınarak anlatıcının melankolik öznelliğinin nasıl oluştuğuna dikkat edildiğinde, bu kısmın da Nedret kadar etkili olabileceği görülür. Nedret'in ölümünden daha önce hem Cek Cansın'la konuşma hem de karşılıklı öldürmeler meydana gelmiştir. Bunlardan hemen sonra anlatıcının gerçeklik algısı bulanmaya başlamıştır. Bir yandan Cek Cansın'ın kim olduğuna, Türkiye'nin geleceğiyle ilgili iddialarını neye dayandırdığına, meydana gelen olaylarla bağlantısına dair şüpheler duymaya başlamış, diğer yandan da karşılıklı öldürmelerde failin kim(ler) olduğuna dair sorgulamaları şiddetlenmiştir. Önceki bölümde ifade edilen Nedret'in vefatı ve Nedret-Sema-Zafer geçişleri bu durumdan sonra başlamıştır. Dolayısıyla bireysel olanla toplumsal olan karş1lklı olarak birbirini etkilemiş, son tahlilde anlatıcının öznelliğini bir müphemiyet krizine sokmuştur. Sevdiği kadın ka- 
dar başka türlü bir toplum tasavvurunu da kaybeden anlatıcının melankolik öznelliği şiddetlenmiştir.

\section{Melankolinin Anatomisi}

"Kapalı İktisat"ın anlatıcısının öznelliğinin bulanmaya başladığı kısımları, aynı zamanda metnin biçimsel heterojenliğinin de arttığı yerlerdir. Anlatıcının zihninde farklı gerçeklik düzlemleri iç içe geçtikçe ve birbirinden ayrılamaz hâle geldikçe tüm tematik ve metinsel öğeler üst üste binmeye başlamaktadır. Nedret'le tanıştıklarında izlediği Hamlet'i tekrar izlediğinde Ofelya, Yorik'in kafatasını toprağa atarken Gülden Karaböcek’in 1978 yılında çıkardığı "Kaybolan Hayaller" şarkısından bir dörtlüğü söylemektedir: "Boşuna kazma mezarcı / Aşkımızı gömemezsin / İkimiz de sevmiştik / Bunu sen bilemezsin" (1978: 459). Yüksek kültürle popüler kültürün iç içe geçtiği bu türden anların yalnızca bir örneğidir bu. Tematik, biçimsel ve türsel karşılaşmaların en yoğunlaştı̆̆ örnek ise anlatıcının Melankolinin Anatomisi kitabına ulaşmasıyla gerçekleşir. Bu kitap yavaş yavaş hayatının anlamı hâline gelir. Her ne kadar ilk olarak kitabın alt başlığındaki "Memento Mori (Öleceğini Asla Unutma)" ifadesinden etkilense de bu kitapta anlatıcıyı asıl etkileyen illüstrasyonlardır. Felemenkçe yazılmış bu metnin tekinsiz ve grotesk resimlerinin her biri anlatıcının geçmiş tecrübelerinden birine işaret etmektedir.

Anlatı başından beri makale, öykü, haber, teyp, şarkı, tiyatro gibi metin ve mecraları iç içe geçirmekte ve öykünün sonundaki bu illüstrasyonlarla da metnin metinler ve mecralar arası niteliğine yeni bir boyut katılmaktadır. Bu nedenle anlatıcının hayatın anlamı olarak gördüğü bu resimlerin gerçekten var olup olmadığı araştırılmıştır. Her ne kadar Richard Burton'ın 1621 yılında yazılmış The Anatomy of Melancholy adında bir kitabı olsa da bu kitap ne illüstrasyonlar içermekte ne de Felemenkçedir. Araştırmalar derinleştirildiğinde söz konusu kitabın Frederik Ruysch'un 1701-1716 yılları arasında 10 cilt olarak Felemenkçe yayımladığı Thesaurus Anatomicus kitabı olduğu tespit edilmiştir. Kitap ayrıntılı olarak incelendiğinde, metinde sözü edilen illüstrasyonların burada yer aldığ1 görülmüştür. Böylelikle İleri’nin “Kapalı İktisat”ta kurduğu göndermeler alanı 18. yüzyıl Hollanda'sına kadar uzanmıştır. Anlatıcı ya da yazar, bilerek ya da bilmeyerek Ruysch'un anatomi kitabını Burton'ın Melankolinin Anatomisi kitabıyla birbirine karıştırmış, böylelikle hem görsellerden hem de melankoli çağrışımından yararlanmıştır.

Aslında Thesaurus Anatomicus'ta, kurmacada Melankolinin Anatomisinde yer alan resimlerden birinde pipa americana türü iki kurbağa iki ayrı kavanoza konmuş olarak çizilmiştir. Bu tür kurbağaların dişileri hamilelik esnasında yavrularını içlerinde değil sırtlarında taşımaktadırlar. Bu özellik ve kavanozlardaki sunuluş tarzları, anlatıcıya insanların bunca yakınken birbirinden 
apayrı olabileceklerini ve Nedret'in hamileliğini hatırlatmaktadır. Başka bir resimdeki hidrosefali örneği çocuk, Tanpınar'ın öyküsünde anlatılanları, deniz gergedanı embriyosu da Sadrazam Koca Hasan Paşa'nın zehirlenme korkusunu çağrıştırmaktadır. Bunun dışında diğer resimlerde sıklıkla (kuvve halindeki ya da filii) doğumu ve ölümü hatırlatan ceninler ve iskeletler yer almaktadır. Her bir görsel, anlatıcının öykü boyunca anlatılan tecrübelerinden biriyle ilişkilenmektedir. ${ }^{6}$ Böylelikle Ruysch'un anatomi kitabını süsleyen ve gerçekleşmemiş ihtimaller, az bulunur örnekler, anormal varlıklarla dolu bu grotesk resimler, anlatıcının hâlini çözebilecek şifrelere dönüşmektedir. Ancak yine de bu illüstrasyonlar, anlatıcının parçalanmı̧̧ öznelliğini rapt ve zapt edemez: "Birçok simgeler çözümsüz kalacak tabiî. Ama olayların bile sayısız gerçeklik içerdiği böylesi bir serüvende, simgeleri çözmek zaten olanaksız” (2007: 464).

\section{Sonuç}

Tartışmayı sona erdirirken, metnin başlığına ve başına tekrar dönülebilir. Dışa açılmadan, iç imkânlarıyla kendini döndüren bir iktisat rejimi olarak kapalı iktisat neden bu öykünün başlığı olarak seçilmiştir? İleri’nin anlatısı aslında en temelde kapalı iktisada dayalı bir toplumu anlatmaktadır. 1970'lerin ithal ikameci ekonomi politikaları bakımından doğruluk payı olan bir saptamadır bu; ancak anlatıda daha çok vurgulanan, toplumsal ilişkilerin ve arzuların kapalı ekonomisidir. Sınıfların, fikirlerin, metaların hareketleri kadar arzunun dolaşımı ve toplumsal ilişkilerin kenetleyici ve sıkıştırıcı yapısının da önemli olduğu bu metinde iç ve dış arasında keskin karşıtlıklar vardır: "Teslim"de anlatıldığ̣ hâliyle kendini dışa kapatan bir toplum yürürlüktedir; bir türlü sağl1klı gerçekleşemeyen doğumlar söz konusudur; hiçbir ilişki tamamlanamamakta, kimse kendini tam anlamıyla aşamamaktadır. Nasıl ki melankolik özne, kaybını kabullenemeyip arzu nesnesini içselleştirerek kendine yediriyorsa, "Kapalı İktisat" mekte, dişarısıyla bir türlü açıklık kurulamamaktadır. Her ne kadar öykünün başında Kadro dergisinden yapılan alıntıların gösterdiği gibi 30'lar Türkiye'si dönemin faşizan ve totaliter rejimlerinden farklı olsa da 70’ler Türkiye'sinde gençlik müesseseleri politikalaş[mış]" (1997: 424), kapalı toplum kendi içine gömülmeye başlamıştır. Bu minvalde anlatıcı, bu kapalı iktisadın avantajlı bir üyesi olmaktan vazgeçip Nedret dolayımıyla kendini aşmaya, başka türlü imkânlara "açık" bir özne olmaya yönelmiştir. Ancak onun da sonu melankolik bir delilik olmuştur. Fakat bu aşma tecrübesi, en azından anlatıcının ve anlatının türdeşliğini kırmış, parçalanmış bir öznenin delilik anlatısı heterojen söylemsel öğeleri olan, çok-katmanlı bir ara-metni mümkün kılmıştır. İleri,

6 Öyküde göndermesi yapılan illüstrasyonların orijinalleri için bkz. Historical Medical Library. 
1980'den 70’lerin sonunun “köklü” meselelerine mesafe alan bir eleştiri geliştirirken aynı zamanda 80 sonrasında daha da yaygınlaşacak yazma tarzlarının habercisi bir metin ortaya koymuştur. Bu makalenin araştırma sürecinde "Kapalı İktisat” 1 somut köklerine, İleri'nin metni oluştururken gerçekleştirdiği dönüştürme işlemine dair bazı bilgilere de ulaşıldı. Bu araştırma sayesinde “Teslim” öyküsü, Milliyet gazetesindeki bir haber ve Frederik Ruysch'un illüstrasyonları ile "Kapalı İktisat" $n$ bağıntıları tespit edildi. Böylelikle, metnin tematik yapısındaki dı̧̧arıda olanı içselleştirme, içe mal etme sürecinin biçimsel bir karşılığının da olduğu, "Kapalı İktisat"ın aynı zamanda başka metin ve mecraları kendine mal etme üzerine kurulu bir yapısının da olduğu açığa çıkmış oldu.

\section{Kaynaklar}

Agamben, Giorgio (2007). “Kayıp Nesne”, Çev. Şeyda Öztürk, Cogito 51, s.258-261. Akatl, Füsun (1982). Bir Pencereden, İstanbul: Adam Yayınları.

Andaç, Feridun (2007). "Kırılgan Anların Öykücüsü”, Selim İleri Kitabı: Şimdi Seni Konuşuyorduk, Haz. Handan İnci, İstanbul: Doğan Kitap, s.41-44.

Batur, Enis (1993). Yazının Ucu, İstanbul: Yapı Kredi Yayınları.

Butler, Judith (2007). "Melankoli ve Toplumsal Cinsiyet - Reddedilmiş Özdeşleşme”, Çev. Zeynep Direk, Cogito 51, s.275-291.

Davies, Peter (2002). The Extreme Right in France 1879 to the Present, Londra: Routledge.

Freud, Sigmund (1993). "Melankoli ve Yas", Çev. R. Uslu ve E. Berksun, Kriz 1 (2), s. $98-103$.

Göle, Münir (2007). “Aşk Melankolisi Diye”, Cogito 51, s.163-169.

Hızlan, Doğan (1996). Kitaplar Kitabı, İstanbul: Yapı Kredi Yayınları.

Hilav, Selahattin (2008a). "Tanpınar Üzerine Notlar”, Bir Gül Bu Karanliklarda: Tanpinar Üzerine Yazılar, Haz. Abdullah Uçman ve Handan İnci, İstanbul: 3F, s.187-200.

_ (2008b). "Kuruntuya Dayanan Eleştirme”, Bir Gül Bu Karanlıklarda: Tanpınar Üzerine Yazılar, Haz. Abdullah Uçman ve Handan İnci, İstanbul: 3F, s.211220.

Hills, Alexandra (2008). "Ingeborg Bachmann's Malina: The (Im)possibility of Writing The Female Self", blue-stocking (Erişim tarihi: 1 Ekim 2015), <http://bluestocking.org.uk /2008/03/01/ingeborg-bachmanns-malina/>.

Historical Medical Library. "Frederik Ruysch - Thesaurus Anatomicus", (Erişim tarihi: 15 Ekim 2015), <http://www.cppdigitallibrary.org/items/browse?advanced\%5 B0\%5D\%5Belement_id\%5D=48\&advanced\%5B0\%5D\%5Btype\%5D=conta 
ins\&advanced\%5B0\%5D\%5Bterms\%5D=Ruysch\%2C+Frederik\%2C+16381731.+Thesaurus+anatomicus\&submit_search=Search>.

İleri, Selim (1980). Bir Denizin Eteklerinde, İstanbul: Altın Kitaplar.

__ (1997). "Kapalı İktisat”, Otuz Yılın Bütün Hikâyeleri, İstanbul: Oğlak Yayınc1lı, s.424-464.

Koçak, Namık (22 Şubat 1977). "Solcu Genci Sağcıların Öldürdüğü Açıklandı”, Milliyet, s.1, 10 .

Macciocchi, Maria A. (1977). Faşizmin Analizi, Çev. Cemal Süreya, İstanbul: Payel Yayınevi.

Mills, Catherine (2008). The Philosophy of Agamben, New York: McGill-Queens University Press.

Rajewsky, Irina O. (2005). "Intermediality, Intertextuality, and Remediation: A Literary Perspective on Intermediality”, Intermédialités 6, s.43-64.

Reich, Wilhelm (1975). Fașizmin Kitle Rubu Anlayışı, Çev. Bertan Onaran, İstanbul: Payel Yayınevi.

Ruysch, Frederik (1701-1716). Thesaurus Anatomicus (Erişim tarihi: 15 Ekim 2015), $<$ http://ruysch.dpc.uba.uva.nl/cgi/t/text/text-idx?page=tekst;c=ruysch;cc=ruys ch;lang=en.>

Tanpınar, Ahmet Hamdi (2011). "Teslim”, Hikâyeler, İstanbul: Dergâh Yayınları, s.214-228.

Yavuz, Hilmi (2008). "Ahmet Hamdi Tanpınar ve Marksizm”, Bir Gül Bu Karanlıklarda: Tanpinar Üzerine Yazılar, Haz. Abdullah Uçman ve Handan İnci, İstanbul: 3F, s.201-209. 


\section{ABSTRACT \\ Explicating Selim İleri’s "Kapalı İktisat”: Melancholy, Politics and Intermediality}

This paper aims to situate the formalist and thematic qualities of Selim İleri's "Kapalı İktisat" (Closed Economy) story in its historical context and within Turkish literature, by analyzing the text. In order to understand the subjectivity of the protagonist, the role of the concept of melancholy will be examined and personal, social and textual manifestations of melancholy in the text will be scrutinized. The concept of melancholy will cast lights on the cruxes in the closed and obscure narrative of the text. The intertextual and intermedial aspects of the story will be foregrounded, and the referents of the text will be identified. It will be shown how the story transformed and appropriated Ahmet Hamdi Tanpinar's short story "Teslim", the illustrations of an eighteenth century anatomist Frederik Ruysch, a news published on Milliyet in 1977 and some essays in Kadro journal. In its thematic and formal structure, "Kapalı İktisat" both signifies a turning point in Selim İleri's authorship and has a pioneering role in the change in Turkish literature of 1980s.

Keywords: Selim İleri, "Kapalı İktisat", melancholy, intertextuality, intermediality 